To determine the amount of malic acid in each experimental tube, these tubes were compared visually to a set of standards prepared by serial dilution and containing known quantities of malate. All experimental tubes and standards contained equal volumes of solution. We were primarily interested in a precise comparison of performances of families from the centre versus those from the periphery. Consequently, pairs of families, one from the centre and one from the periphery, were kept adjacent to one another throughout the experiment. The results were analysed using the Wilcoxon signed-ranks test which is most appropriate for paired comparisons.

Table 1 Malate Contents ( $\mu \mathrm{g} / \mathrm{ml}$, of Root Extract) of Roots of Centre Families (C) and Periphery Families (P) Grown in Moist and Wet Soil

\begin{tabular}{|c|c|c|c|c|c|c|}
\hline \multirow{3}{*}{ Pair } & \multicolumn{4}{|c|}{ Soil conditions } & \multirow{2}{*}{\multicolumn{2}{|c|}{$\begin{array}{l}\text { Reaction to in- } \\
\text { creased moisture * }\end{array}$}} \\
\hline & \multicolumn{2}{|c|}{ Moist } & \multicolumn{2}{|c|}{ Wet } & & \\
\hline & $\mathrm{C}$ & $\mathrm{P}$ & $\mathrm{C}$ & $\mathbf{P}$ & C & $\mathbf{P}$ \\
\hline 1 & 0.40 & 0.65 & 1.20 & 0.15 & + & - \\
\hline 2 & 0.40 & 0.65 & 9.60 & 0.15 & + & - \\
\hline 3 & 0.40 & 0.65 & 4.80 & 2.40 & + & + \\
\hline 4 & 0.40 & 0.65 & 2.40 & 1.20 & + & + \\
\hline 5 & 0.40 & 0.65 & 1.20 & 9.60 & + & + \\
\hline 6 & 0.40 & 0.65 & 1.20 & 1.20 & + & + \\
\hline 7 & 0.40 & 0.65 & 2.40 & 0.60 & + & - \\
\hline 8 & 0.65 & 0.40 & 1.20 & 0.60 & + & + \\
\hline 9 & 0.40 & $<0.01$ & 4.80 & 0.30 & + & + \\
\hline 10 & 0.05 & 0.40 & 13.00 & 0.15 & + & - \\
\hline $\bar{X}$ & 0.39 & 0.53 & 4.18 & 1.62 & + & + \\
\hline \multicolumn{2}{|c|}{ Stat. signif. } & vS & \multicolumn{2}{|c|}{$P<0.025$} & $P<0.001$ & NS \\
\hline
\end{tabular}

* This column represents the change in malate contents as soil moisture is increased.

Table 1 shows the malate contents in roots of all families in moist and wet conditions. In moist conditions, roots of families from the periphery contain slightly more malate than roots of families from the centre, but the difference is not statistically significant. In family pairs grown in saturated soil, however, there is a much greater accumulation of malate in the roots of centre families. This difference is statistically significant. A summary of the reaction to an increase in soil moisture and concomitant decrease in soil oxygen is provided in the third column of Table 1. In all ten families from the centre, there was a sizable increase of malate accumulation. The response is statistically highly significant. In periphery families, there was an increase in six families and a decrease in four families. The average response was an increase which is not statistically significant.

The significant difference in the response to flooding of centre and periphery plants can be understood in terms of the difference in habitats occupied by those plants. Four families from the periphery where soils are seldom saturated showed a decrease in malate contents which may be due to the triggering of "malic" enzyme activity". Six families from the periphery showed some increase in malate contents suggesting they are at least somewhat adapted to flooded conditions. In all families from the centre where flooding is commonplace, the response was a significant increase in malate contents and this increase was significantly larger than the increase in periphery families. Intra-population differentiation for several other characteristics has also been observed within the $V$. peregrina population studied $^{9}$. The distance between the centre and periphery of this population is $2-5 \mathrm{~m}$ depending on the location, and the observations reported suggest that differentiation, perhaps produced by disruptive selection, can be maintained over such short distances.

We thank Professor H. G. Baker for his help. The experimental work was supported by a grant from the National Science Foundation. Y. B. L. was a graduate trainee under a training grant from the Research Training Grants Branch, National Institute of General Medical Sciences.

YAN B. LINHART

Department of Environmental, IRENE BAKER

Population and Organismic Biology,

University of Colorado, Boulder, Colorado 80302

Received November 7; revised December 27, 1972.

1 Ehrlich, P. R., and Raven, P. H., Science, 165, 1228 (1969).

2 Bradshaw, A. D., in Evolutionary Biology (edit. by Dobzhansky, T., Hecht, M. K., and Steere, W. C.), 5, 25 (Appleton-CenturyCrofts, New York, 1972).

3 Pennell, F. W., Rhodora, 23, 1 (1921).

4 Munz, P. A., A California Flora (University of California Press, Berkeley, 1959).

5 Crawford, R. M. M., Ber. dt. Bot. Ges., 82, 111 (1969).

6 Crawford, R. M. M., and Tyler, P. D., J. Ecol., 57, 235 (1969).

7 McManmon, M., and Crawford, R. M. M., New Phytol., 70, 299 (1971).

8 Mulligan, G. A., Canad. J. Bot., 50, 1767 (1972).

9 Linhart, Y. B., dissertation, Univ. California, Berkeley (1972).

10 Bergmeyer, H. U., Methods of Enzymatic Analysis (Academic Press, New York, 1965).

\section{Pollution of Beaches: Reply to Regnier and Park}

Regnier and Park ${ }^{1}$ do not appear fully to have appreciated the significant point that emerged from my finding ${ }^{2}$ that much higher concentrations of antibiotic-resistant and sensitive coliform organisms were present in specimens of water taken from rivers flowing through urban areas than were present in similar specimens taken from rivers flowing through rural areas. This is that human beings were the main source of the sewage pollution of the rivers and that domestic animals were a comparatively unimportant source. The fact that one cannot differentiate the two kinds of specimens from each other by reference to the ratio of the numbers of resistant and sensitive organisms they contain is therefore irrelevant.

Because of my observations on river waters, domestic animal sewage was not thought to be worthy of consideration as a major source of the pollution I found during my later observations on coastal bathing waters ${ }^{3}$. Also, there have been several reports, including the one referred to in my paper ${ }^{4}$, implicating human sewage in this respect and, as one would expect, there was no evidence of any farm waste being drained into the beaches I examined.

My comment that the finding of $\mathrm{R}^{+}$Escherichia coli in sea water provides "stronger evidence of contamination with human sewage", to which Regnier and Park specifically refer, was not made in reference to the possible implication of domestic animal sewage but in reference to the possible implication of excreta from marine life and wild birds-this is clearly stated in my paper.

In view of the many reports of European beaches being closed because of human sewage pollution and even of people being fined for bathing in them, I am surprised that Regnier and Park adopt what, to me, seems a rather complacent attitude to the state of our beaches. I cannot share their view. Although I would not class most of the ones I examined as grossly polluted, some of them, Penarth and Ogmore for example, must have been getting near to qualifying for that definition.

Finally, with regard to the public health aspect, I feel that hygienic principles can mean very little if they condone the immersion of the human body in what are really suspensions of human faeces.

7 Quaker Close, Kings Ripton, Huntingdon

\section{H. WILliams SMITH}

Received October 19, 1972.

1 Regnier, A. P., and Park, R. W. A., Nature, 239, 408 (1972).

2 Smith, H. W., Nature, 228, 1286 (1970).

3 Smith, H. W., Nature, 234, 155 (1971).

4 Report, J. Hyg. Camb., 57, 435 (1959). 